\title{
Die Verband tussen Gesproke en Geskrewe Taal van Leergestremdes
}

\author{
Idillette Oosthuizen, Brenda Louw en Isabel Uys
}

Departement Kommunikasiepatologie, Universiteit van Pretoria

\begin{abstract}
OPSOMMING
Die ondersoek het dit ten doel gehad om die verband tussen gesproke taal, geskrewe taal en fonologiese prosessering te bepaal. Die empiriese opname is deur middel van'n beskikbaarheidseleksie op nege Afrikaanssprekende taalleergestremde leerlinge in graad-twee uitgevoer. Ooreenkomstig voorafbepaalde doelstellings is gesproke taalparameters, geskrewe taalparameters en fonologiese prosesseringsparameters geïdentifiseer. Die proefpersone se peil van funksionering op die onderskeie parameters, sowel as die verwantskap tussen die parameters is kwalitatief en kwantitatief ontleed en beskryf. Die resultate van hierdie empiriese opname toon dat betekenisvolle korrelasies tussen gesproke taal, geskrewe taal en fonologiese prosesseringsvaardighede by die betrokke taalleergestremde proefpersone voorgekom het.
\end{abstract}

\section{ABSTRACT}

The aim of this study was to explore the interrelationship between spoken language, written language and phonological processing. The empirical study was administered on nine Afrikaans-speaking, language-impaired children in grade two by means of accidental sampling. Conformable to predetermined objectives, spoken language parameters, written language parameters, and phonological processing parameters were identified. The subjects' level of functioning with regard to each parameter, and the interrelationship between these parameters were qualitatively and quantitatively analysed and described.

The results of this study indicated significant correlations between spoken language, written language and phonological processing abilities of the selected language impaired subjects.

SLEUTELWOORDE: taalleergestremdheid, gesproke taal, geskrewe taal, fonologiese prosessering.

Geletterdheid, geletterdheidsontwikkeling en voorlopers tot geletterdheid is tans van die mees kontensieuse onderwerpe binne die vakgebied van Spraak-Taalpatologie. 'n Heroriëntasie in navorsers én beroepslui se siening van geletterdheid het gedurende die afgelope eeu en veral gedurende die afgelope dekade plaasgevind. Voor 1970 is leesprobleme as 'n uitval in visueel-perseptuele prosesse beskou. Johnson en Myklebust (1967) het egter die grondslag gelê vir die perspektief dat leesprobleme, en gevolglik ook skryfprobleme, 'n taalgebaseerde uitval is en nie noodwendig ' $n$ refleksie van kognitiewe of visueelperseptuele beperkinge nie (Kamhi \& Catts, 1991).

Hierdie verandering in siening van navorsers en beroepslui bring mee dat taal as vertrekpunt vir die ontwikkeling van gesproke en geskrewe taalvermoëns beskou word. Die verandering stel opnuut uitdagende en opwindende eise aan die spraak-taalterapeut. Juis vanweë die spraak-taalterapeut se besondere kennis van taalontwikkeling en taalprobleme, speel lede van hierdie beroep 'n kardinale rol in diagnose en intervensie van die kind met gesproke en geskrewe taalprobleme. Die Suid-Afrikaanse Vereniging vir Spraak-Taal-Gehoor (SAVSTG) (1990: 2) ondersteun die standpunt dat die spraaktaalterapeut ' $n$ belangrike rol speel tydens diagnose en intervensie van beide gesproke taalprobleme en geskrewe taalprobleme.

Dit blyk dat vanweë die feit dat die spraak-taalterapeut 'n onmiskenbare rol by beide gesproke en geskrewe taal speel, dit noodsaaklik geword het om weg te beweeg van 'n diskrete-puntbenadering waar gesproke taal alleen aangespreek word. 'n Breër en dus holistiese benadering word aanbeveel waar die kind in totaliteit gesien word en beide gesproke en geskrewe taalprobleme as uitvloeisel van 'n onderliggende taalprobleem behandel word.

Die noue interaksie tussen gesproke en geskrewe taalprobleme bestaan en die feit dat die spraak-taalterapeut gevolglik albei dié komponente tydens diagnose en intervensie by die leergestremde kind behoort aan te spreek, impliseer dat groter eise en hoër vaardigheidsvlakke aan beroepslui gestel word. Dit is van kardinale belang dat navorsing oor taalprobleme, en die gevolg van taalprobleme, voortgesit moet word sodat resente bevindings by die bestaande databasis gevoeg kan word (Klecan-Aker \& Kelty, 1990). As gevolg van ontwikkeling in dié vakgebied, ontstaan daar voortdurend nuwe vraagstukke wat navorsing vereis. Nuwe kennis moet voortdurend by bestaande kennis gevoeg word, sodat die spraak-taalterapeut'n teoretiese basis kan formuleer wat as grondslag kan dien vir effektiewe diagnosering en intervensie by die taalleergestremde kind. 
In die lig van resente navorsingsbevindinge word die spraak-taalterapeut gekonfronteer met vraagstukke soos wat die spesifieke aard van die verband tussen gesproke en geskrewe taalprobleme werklik is (Stackhouse, 1990). Dit is vir verantwoordbare beroepsoptrede noodsaaklik dat die spraak-taalterapeut kennis moet dra van hierdie vraagstukke. Vanweë die noue verwantskap tussen gesproke taalfunksionering en geskrewe taalfunksionering kan gesproke taal en geskrewe taal nie as sodanig in isolasie benader word nie.

In die verlede is die rol van die spraak-taalterapeut afgebaken en beperk tot evaluering, diagnose en intervensie van gesproke taalprobleme. Hierdie fragmentariese beskouing het tot gevolg gehad dat daar tans'n leemte in kennis oor die spesifieke verwantskap tussen gesproke en geskrewe taal bestaan. Bo en behalwe dat gesproke taal en geskrewe taal as interafhanklike vaardighede beskou word, word daar tans gespekuleer oor die invloed van fonologiese prosessering op beide hierdie vaardighede.

Daar word in resente publikasies (Stackhouse, 1990; Kamhi \& Catts, 1991) gehipotetiseer dat gesproke en geskrewe taalprobleme moontlik die manifestasie van dieselfde onderliggende fonologiese prosesseringsprobleem is. Stackhouse (1990) beskryf pertinent die moontlikheid van spraak-, lees- en spelprobleme as verskillende manifestasies van dieselfde onderliggende fonologiese prosesseringsprobleem.

Waar kinders met gesproke en geskrewe taalprobleme presenteer, ontstaan die vraag of 'n onderliggende fonologiese prosesseringsprobleem kan bydra, of selfs die primêre oorsaak van beide gesproke taalprobleme en geskrewe taalprobleme, kan wees. Indien laasgenoemde wel die geval is, impliseer dit dat ' $n$ verbetering in fonologiese prosesseringsvermoëns ' $n$ verbetering in beide die gesproke taalvaardigheid en geskrewe taalvaardigheid teweeg sou kon bring.

Die behoefte om meer inligting oor die spesifieke aard van die verwantskap tussen gesproke en geskrewe taal te verkry, asook of 'n onderliggende faktor, naamlik fonologiese prosesseringsprobleme 'n oorsaak van beide gesproke taalprobleme en geskrewe taalprobleme is, is in die literatuur geïdentifiseer (Van Kleeck, 1990 en 1992; Kamhi \& Catts, 1991). Dit blyk egter sinvol te wees om resente vraagstukke rakende gesproke en geskrewe taalprobleme binne die leergestremde populasie te ondersoek, aangesien leergestremde kinders 'n hoë-risikopopulasie is om met beide gesproke en geskrewe taalprobleme te presenteer (Reid, Hresko \& Swanson, 1991; Klecan-Aker \& Kelty, 1990).

Reid et al. (1991) ondersteun die standpunt dat navorsing oor die leergestremde populasie ten spyte van uitgebreide studie steeds geregverdig word. Hul meen dat beperkte aandag aan basiese navorsing en aan die ontwikkeling van teorieë geskenk word, en dat navorsing oor leergestremdheid uiters swak georganiseer is. Daar word voorgestel dat intensiewe gekoördineerde wetenskaplike navorsing sal bydra tot die oplossing van fundamentele probleme rakende leergestremdheid (Reid et al., 1991).

Nye, Foster en Seaman (1987) beklemtoon die belang van navorsing, asook die waarde van intervensie by die leergestremde populasie. Hul motiveer hul siening deur wetenskaplik te bewys dat taalleergestremde kinders se taalfunksionering merkwaardige verbetering getoon het nadat ' $n$ intensiewe taalintervensieprogram met hulle gevolg is. Dit blyk dat die taalvaardigheidsvlakke van dié taalleergestremde kinders betekenisvolle verbetering getoon het, en dat navorsing op hierdie spesifieke populasie soveel te meer sinvol blyk te wees wanneer daar na hul vorderingsmoontlikhede gekyk word.

Beroepsfunksies van die spraak-taalterapeut impliseer die hantering van kommunikasie- afwykings (Uys, 1993), Kommunikasie-afwykings sluit onder andere taalprobleme in wat presenteer op beide gesproke taalvlak en geskrewe taalvlak. Wanneer fonologiese prosesseringsvaardighede as voorvereiste vir effektiewe funksionering op geskrewe taalvlak en gesproke taalvlak beskou word (Stackhouse, 1990 ), word fonologiese prosessering onomwonde deel van kommunikasie-afwykings wat onder andere deur die spraak-taalterapeut hanteer word.

Alhoewel die spraak-taalterapeut as lid van die transprofessionele span betrokke is by evaluering, diagnose en intervensie van leergestremde leerlinge, word die spraaktaalterapieberoep as sodanig met kommunikasieafwykings (wat kommunikasie-afwykings van leergestremdes insluit) geassosieer.

Die doel van hierdie studie is gevolglik om meer inligting in te win aangaande die aard van die verband tussen gesproke en geskrewe taalvermoëns van leergestremde leerlinge aangesien dit waardevolle kliniese riglyne vir evaluering, diagnosering en intervensie by die leergestremde populasie verskaf. Meer effektiewe bemoeienis rakende gesproke en geskrewe taalprobleme kan uit die beskikbaarheid van hierdie inligting voortvloei.

\section{METODE}

As agtergrond tot die ondersoek is doelstellings geformuleer.

\section{DOEL}

Die doel van die ondersoek is om die funksionering van 'n groep taalleergestremde leerlinge in onderskeidelik gesproke taalfunksionering, geskrewe taalfunksionering en fonologiese prosessering te ondersoek asook om die aard van die verband tussen gesproke taalvermoëns, geskrewe taalvermoëns en fonologiese prosesseringsvermoëns te bepaal. Die volgende subdoelstellings is geformuleer om die doel te bereik:

1. Identifikasie van die onderskeie gesproke taalparameters, geskrewe taalparameters en fonologiese prosesseringsparameters.

2. Bepaling van proefpersone se peil van funksionering op die onderskeie parameters.

3. Ondersoek na die verwantskap tussen die onderskeie parameters.

\section{NAVORSINGSONTWERP}

Hierdie studie is in die vorm van 'n kwalitatiewe en kwantitatiewe gestruktureerde beskrywende-opname uitgevoer (Leedy, 1989).

\section{PROEFPERSONE}

Proefpersone is deur middel van die beskikbaarheidseleksie (Leedy, 1989) gekies en het aan die volgende kriteria voldoen: 
1. Afrikaans moet die moedertaal of dominante taal wees.

2. Normale visuele en ouditiewe vermoëns moet voorkom.

3. Serebrale gestremdheid mag teenwoordig wees.

4. Spesifieke leergestremdheid moet by alle proefpersone gediagnoseer wees.

5. Proefpersone moet graad twee skoliere wees in'n skool vir Buitengewone Onderwys.

6. Proefpersone moet oor 'n gemiddelde of bo-gemiddelde intelligensie beskik.

'n Totale aantal van nege proefpersone is in hierdie empiriese studie betrek. Die inligting vir proefpersoonbeskrywing word volledig in Tabel 1 saamgevat.

\section{MATERIAAL EN APPARAAT}

Die apparaat en materiaal word in drie afsonderlike afdelings bespreek, naamlik:

\section{Meetinstrumente om gesproke taal te evalueer}

Meetinstrumente wat geselekteer is om gesproke taal te evalueer word opsommend in Tabel 2 weergegee.

\section{Meetinstrumente om fonologiese prosessering te evalueer}

Aangesien daar nog geen gestandaardiseerde toets bestaan wat fonologiese prosesseringsvermoëns evalueer nie, het die navorser na deeglike literatuurverkenning (Van Kleeck, 1992; Stackhouse, 1990)' $n$ eie toets ontwerp (vergelyk Bylae A), wat spesifiek die segmentering van die akoestiese stroom evalueer. Die toets bestaan uit drie subtoetse, naamlik

- subtoets een wat die segmentering van 'n sin in sy afsonderlike woordkomponente evalueer,

- subtoets twee wat die segmentering van 'n woord in sy afsonderlike sillabes evalueer en

- subtoets drie wat die segmentering van 'n woord in sy afsonderlike klankkomponente evalueer.

Die subtoetse is so geformuleer dat verskillende klankkombinasies wat in Afrikaans voorkom, deur die subtoetse gedek word.

\section{Meetinstrumente om geskrewe taal te evalueer ,}

Meetinstrumente wat geselekteer is om geskrewe taal te evalueer word opsommend in Tabel 3 weergegee.

\section{OPNAME PROSEDURES}

Die prosedure is soos volg toegepas:

\section{Data-insamelingsprosedure}

Die volgende prosedure is gevolg:

- Toestemming is van die skoolhoof verkry om die betrokke empiriese studie op die graad twee leerlinge uit te voer.

- 'n Profielblad met identifiserende inligting rakende alle proefpersone is deur die navorser vir elke proefpersoon voltooi.

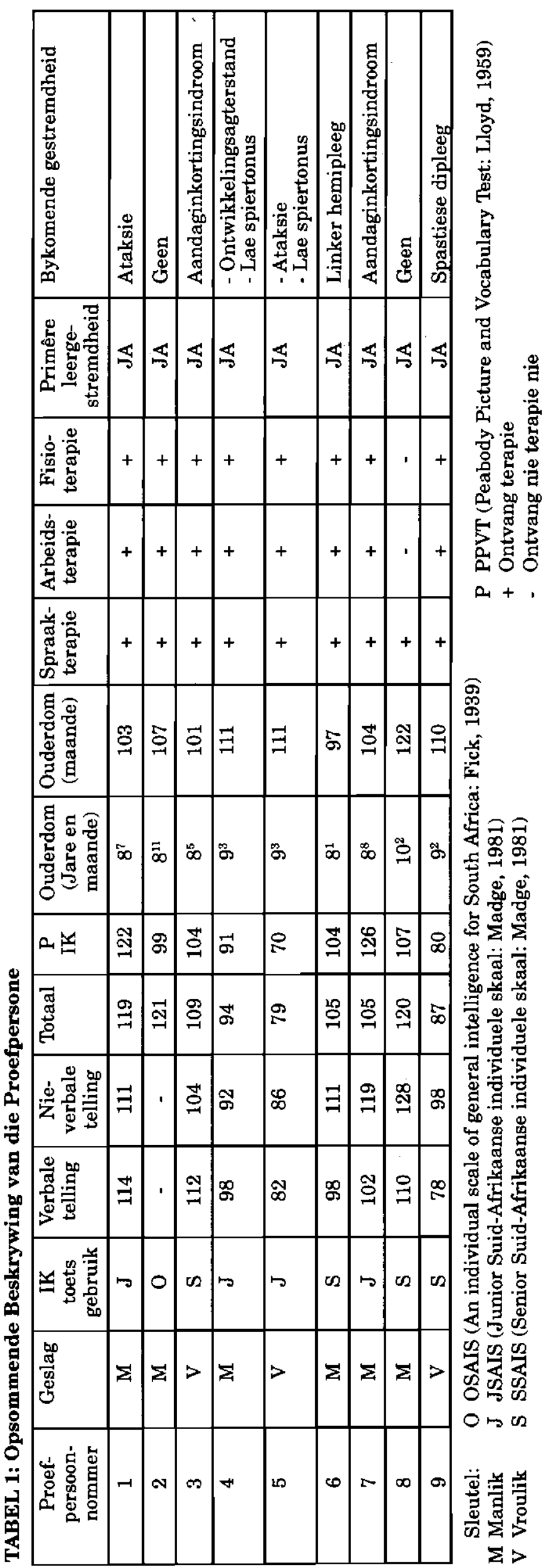


- Proefpersone is aan spraak-taalterapeute en 'n remediërende onderwyseres toegeken vir uitvoering van diagnostiese toetsing. Spesifieke voorskrifte is gevolg ten opsigte van uitvoering van toetse.

- Akkurate beskrywing van data is op gefotostateerde vorms aangeteken.

- 'n Statistikus is geraadpleeg vir dataverwerking.

\section{Data-analise}

Om doelstelling een te bereik is alle veranderlikes in die data-definisie gedefinieer (vergelyk Bylae B) en gekategoriseer onder gesproke taalparameters, geskrewe taalparameters en fonologiese prosesseringsparameters.

Om die tweede doelstelling te bereik is die volgend stappe beplan (Leedy, 1989):

TABEL 2: Meetinstrumente wat geselekteer is om gesproke taal te evalueer

\begin{tabular}{|c|c|c|c|}
\hline Evaluasie-area & Meetinstrument & Motivering vir keuse van toets & Bron \\
\hline I Taalinhoud & $\begin{array}{l}\text { * Peabody Picture and Vocabu- } \\
\text { lary Test (PPVT) (Vertaalde } \\
\text { Afrikaanse Weergawe) } \\
\text { * Test for Auditory Comprehen- } \\
\text { sion of Language (TACL-R) } \\
\text { (Vertaalde Afrikaanse Weer- } \\
\text { gawe) }\end{array}$ & $\begin{array}{l}\text { * Die PPVT gee 'n verbale intelligensiekwosiënt } \\
\text { wat effektief met verbale tellings, soos gemeet } \\
\text { deur die JSAIS (Madge, 1981) of SSAIS } \\
\text { (Madge, 1983) vergelyk kan word. Die PPVT } \\
\text { is verder geselekteer aangesien die Afrikaan- } \\
\text { se Reseptiewe Woordeskattoets (ARW), nog } \\
\text { nie beskikbaar is nie. } \\
\text { * Inligting met betrekking tot die proefpersoon } \\
\text { se reseptiewe taal word in 'n kort tyd verkry. } \\
\text { Inligting behels naamlik } \\
\text { - woordklasse en relasies, } \\
\text { - grammatikale morfeme en } \\
\text { - uitgebreide sinne. } \\
\text { 'n Ouderdomspeil word verkry wat intertoets- } \\
\text { relasies en interproefpersoonrelasies verge- } \\
\text { maklik. }\end{array}$ & \begin{tabular}{|l}
$*$ Oorspronklike \\
samesteller \\
-Lloyd, 1959 \\
\\
\\
* Oorspronklike \\
samesteller \\
-Carrow-Wool. \\
folk, 1985
\end{tabular} \\
\hline II Taalvorm & $\begin{array}{l}\text { * Die Afrikaanse Semantiese } \\
\text { Taal-evalueringsmedium (AST) } \\
\text {-Subtoets 2: Woorddefinisies } \\
\text { * Toets vir Mondelinge Taal- } \\
\text { produksie (TMT) }\end{array}$ & $\begin{array}{l}\text { * Die AST is 'n resente toets wat ekspressiewe } \\
\text { uitinge (woordbeskrywing) op 'n maklike en } \\
\text { informele wyse evalueer. Die omskakeling } \\
\text { van die roupunt na 'n ontwikkelingsvlak word } \\
\text { op 'n tabel afgelees, en langdradige verwer- } \\
\text { kings van resultate word gevolglik daardeur } \\
\text { uitgeskakel. Deur middel van die ouderdoms- } \\
\text { vlak kan effektiewe interproefpersoon en } \\
\text { intertoetsrelasies afgelei word. } \\
\text { * Die TMT verskaf metings vir 16 fasette van } \\
\text { taalproduksie wat saam produktiwiteit, } \\
\text { sintaktiese kompleksiteit, korrektheid, } \\
\text { vlotheid en inhoud dek. Stanege-tellings kan } \\
\text { effektief in statistiese vergelykings gebruik } \\
\text { word. }\end{array}$ & \begin{tabular}{|c|} 
* Pretorius, 1989 \\
*Vorster, 1980 \\
$\vdots$ \\
$\vdots$ \\
$\vdots$
\end{tabular} \\
\hline III Taalgebruik & * Pragmatiek-evaluasie & $\begin{array}{l}\text { * Hierdie vraelys bestaan uit'n kort en bondige } \\
\text { metode waardeur verskeie aspekte van prag- } \\
\text { matiek geëvalueer word, Direkte terapie- } \\
\text { leidrade word verder deur die vraelys verkry. } \\
\text { Die roupunt uit } 20 \text { kan effektief met dié van } \\
\text { ander leerlinge vergelyk word. }\end{array}$ & $\begin{array}{l}\text { * Creaghead, } \\
1984\end{array}$ \\
\hline $\begin{array}{l}\text { IV Ouditiewe } \\
\text { prosessering }\end{array}$ & $\begin{array}{l}\text { * Pendulum } \\
\text { Die volgende areas word getoets, } \\
\text { naamlik } \\
\text {-ouditiewe storiegeheue, } \\
\text {-ouditiewe opeenvolgende geheue, } \\
\text {-ouditiewe sluiting, } \\
\text {-ouditiewe analise en } \\
\text {-ouditiewe sintese. }\end{array}$ & $\begin{array}{l}\text { * Die Pendulum is gekies aangesien die toets } \\
\text { maklik uitvoerbaar is. 'n Pertinente ouder- } \\
\text { doms- en standerdpeil word ook verkry, wat } \\
\text { effektief in statistiese vergelykings gebruik } \\
\text { kan word. Tallal (1980 in Stackhouse, 1990) } \\
\text { beklemtoon ook die verband tussen lees- en } \\
\text { ouditief-perseptuele probleme, met die gevolg } \\
\text { dat ouditiewe prosessering noodwendig deel } \\
\text { van die toetsbattery moet uitmaak. }\end{array}$ & * Struwig, 1984 \\
\hline
\end{tabular}


* 'n Minimum-en maksimumwaarde word vir alle veranderlikes bepaal.

* Veranderlikes met negatiewe tellings word omgeskakel na positiewe tellings sodat hoër toetstellings, beter prestasie by die toetsling impliseer.

- Herskalering vind plaas met ander woorde, alle veranderlikes word getransformeer na 'n nul-eenintervalskaal sodat alle veranderlikes met mekaar vergelykbaar kan wees, en toetsresultate word op 'n kwalitatiewe wyse beskryf om sodoende die moontlike verbande en verklarings vir die verbande uit te wys, al dan nie.

Om die derde doelstelling te bereik, is die volgende stappe beplan (Leedy, 1989):

- Pearson se parametriese korrelasietegniek word toegepas om sodoende die korrelasie-koëffisiënt te bepaal.

- Na aanleiding van die waarde van Pearson se korrelasiekoëffisient kan daar bepaal word of betekenisvolle verbande tussen gesproke taalparameters, geskrewe taalparameters en fonologiese prosesseringsparameters bestaan, al dan nie.

- Spearman se nie-parametriese korrelasietegniek word toegepas om sodoende die korrelasiekoëffisient te bepaal na aanleiding van die waarde van Spearman se korrelasiekoëffisient wat rangordekorrelasies bepaal.

\section{RESULTATE EN BESPREKING}

Die resultate word vervolgens aangebied.
I IDENTIFIKASIE VAN ONDERSKEIE PARAMETERS OP. GESPROKE TAALVLAK, GESKREWE TAALVLAK EN FONOLOGIESE PROSESSE. RINGSVLAK

Die toepaslike veranderlikes word vir die doel van die studie in Tabel 4 weergegee.

\section{IIUITEENSETTING VAN PROEFPERSOON FUNKSIONERING OP DIE ONDERSKEIE PARA- METERS}

Die parameters wat 'n betekenisvolle verskil met kronologiese ouderdom van die groep proefpersone aandui, word in Tabel 5 saamgevat.

\section{BESPREKING EN VERKLARING VAN DIE'AARD VAN DIE KORRELASIES WAT TUSSEN GESPROKE TAALPARAMETERS, GESKREWE TAALPARAMETERS EN FONOLOGIESE PROSESSERINGSPARAMETERS GEÏDEN- TIFISEER IS}

Die aard van die korrelasies tussen gesproke taalparameters, geskrewe taalparameters en fonologiese prosesseringsparameters word in Tabel 6 saamgevat.

Alhoewel outeurs verskil oor die spesifieke aard van gesproke taaluitvalle, geskrewe taaluitvalle en fonologiese prosesseringsuitvalle by taalleergestremdes, asook oor die verband tussen hierdie vaardighede, is outeurs en navorsers dit eens dat taalleergestremde leerlinge 'n hoërisiko-populasie is, omdat hulle met uitvalle op hierdie

TABEL 3: Evaluasie-areas en meetinstrumente wat geselekteer is om geskrewe taal te evalueer

\begin{tabular}{|c|c|c|c|}
\hline $\begin{array}{c}\text { Areas wat } \\
\text { geëvalueer word }\end{array}$ & Meetinstrument & $\begin{array}{l}\text { Motivering vir keuse van toets en afleidings wat } \\
\text { gemaak kan word uit die verkreë toetsresultate }\end{array}$ & Bron \\
\hline \multirow[t]{2}{*}{ I. LEESVERMOË } & $\begin{array}{l}\text { - Individuele } \\
\text { diagnostiese } \\
\text { leestoets } \\
\text { (Prosalees en } \\
\text { begrip) }\end{array}$ & $\begin{array}{l}\text { - Inligting word verkry aangaande'n leerling se visuele } \\
\text { begrip, aangesien hul self'n voorgeskrewe stuk moet } \\
\text { lees en daarna mondelinge antwoorde op vrae moet } \\
\text { gee. } \\
\text { - Inligting word ook verkry aangaande 'n kind se } \\
\text { visuele storiegeheue. }\end{array}$ & $\begin{array}{l}\text { - Grové \& Haupt- } \\
\text { fleisch (1984) }\end{array}$ \\
\hline & $\begin{array}{l}\text { - Een-minuut- } \\
\text { leestoets } \\
\vdots\end{array}$ & $\begin{array}{l}\text { - Inligting aangaande die kind se leesspoed word } \\
\text { verkry. } \\
\text { - Afleidings kan gemaak word m.b.t. hul sintesevermoë } \\
\text { en begrip. } \\
\text { - Leerlinge met 'n hoë IK is geneig om hulself te } \\
\text { korrigeer. }\end{array}$ & $\begin{array}{l}\text { Transvaalse } \\
\text { Onderwys- } \\
\text { departement } \\
\text { (ongedateer) }\end{array}$ \\
\hline \multirow[t]{3}{*}{$\begin{array}{l}\text { II. SPELLING- } \\
\text { VERMOË }\end{array}$} & $\begin{array}{l}\text { - K3 Skolastiese } \\
\text { toets }\end{array}$ & $\begin{array}{l}\text { Bo en behalwe inligting oor 'n leerling se spelling- } \\
\text { vermoë kan afleidings gemaak word aangaande die } \\
\text { kind se begrip van stillees. }\end{array}$ & $\begin{array}{l}\text { - Transvaalse } \\
\text { Onderwysdeparte- } \\
\text { ment (ongedateer) }\end{array}$ \\
\hline & $\begin{array}{l}\text { - IPV Spelling- } \\
\text { toets }\end{array}$ & $\begin{array}{l}\text { Inligting aangaande die leerling se spellingvermoë } \\
\text { word verkry in terme van woorde wat progressief } \\
\text { moeiliker gegradeer is. }\end{array}$ & $\begin{array}{l}\text { Universiteit van } \\
\text { Wes-Kaapland } \\
\text { (ongedateer) }\end{array}$ \\
\hline & - TOD taaltoets & $\begin{array}{l}\text { Inligting word verkry aangaande stillees-begrip. } \\
\text { - Inligting word met betrekking tot spelling en begrip } \\
\text { verkry aangesien vrae skriftelik beantwoord moet } \\
\text { word. }\end{array}$ & $\begin{array}{l}\text { Transvaalse } \\
\text { Onderwysdeparte- } \\
\text { ment (ongedateer) }\end{array}$ \\
\hline
\end{tabular}




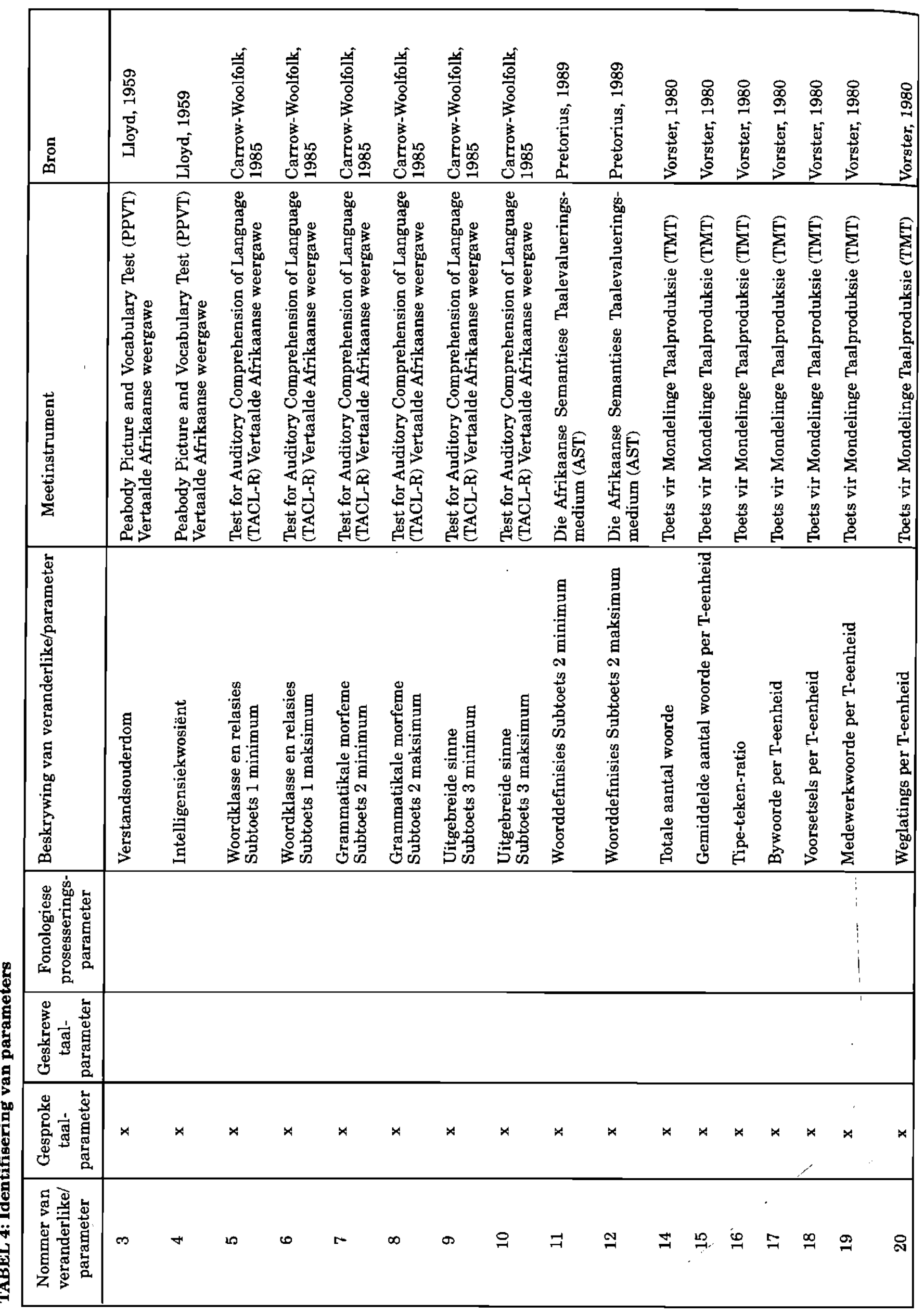

The South African Journal of Communication Disorders, Vol. 42, 1995 


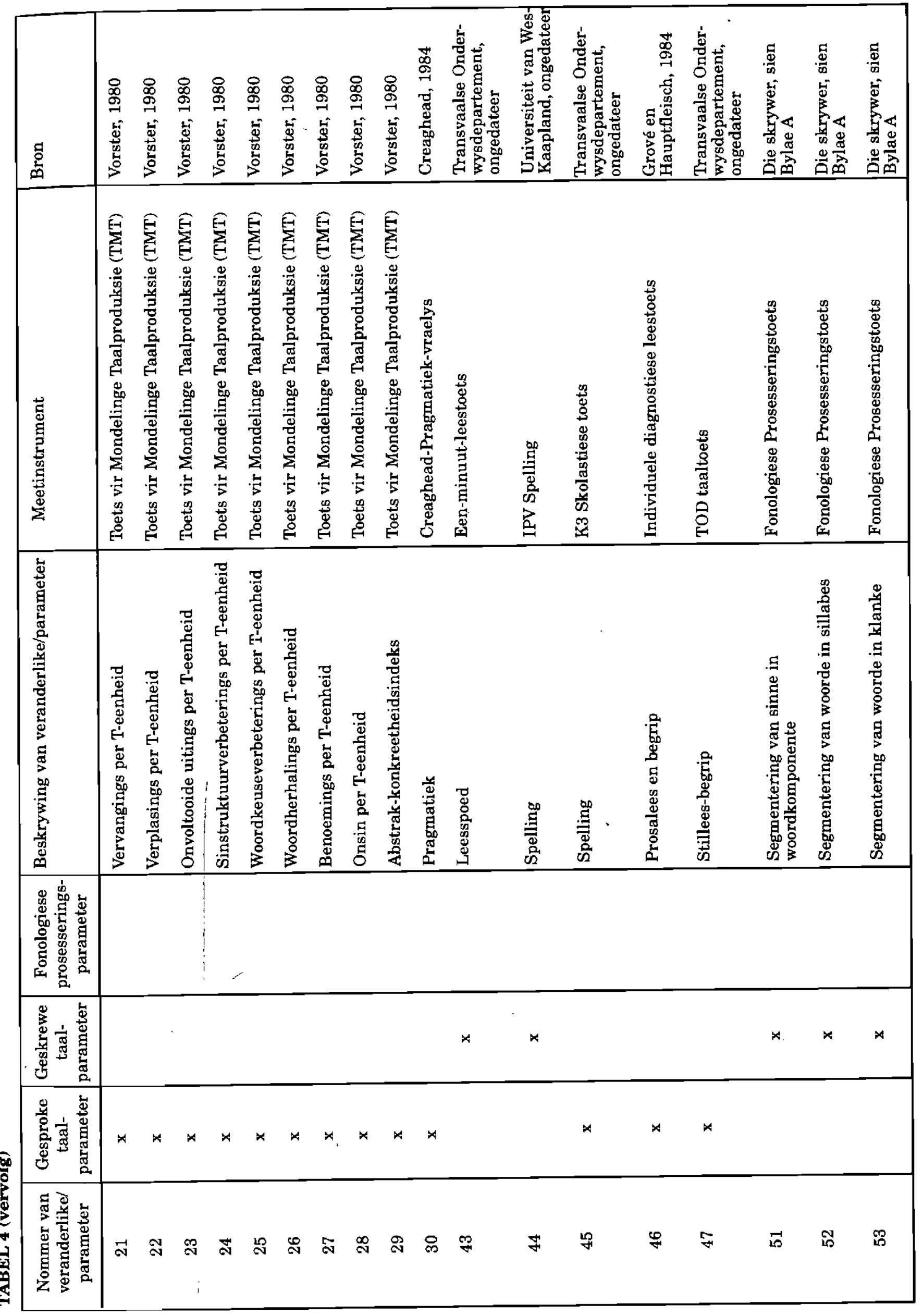

Die Suid-Afrikaanse Tydskrif vir Kommunikasieafwykings, Vol. 42, 1995 
vlakke presenteer (Reid et al., 1991; Klecan-Aker \& Kelty, 1990; Stackhouse, 1990; Van Kleeck, 1992).

Volgens die resultate van dié studie toon slegs ses van die 35 geïdentifiseerde parameters 'n betekenisvolle verskil op 'n $5 \%$ en $10 \%$ betekenispeil met die kronologiese ouderdom van die groep proefpersone. Hierdie verskille is van so 'n aard dat dit die implikasie het dat die spesifieke groep proefpersone bo hul kronologiese ouderdom presteer met betrekking tot begrip vir woordklasse en verhoudings, begrip vir grammatikale morfeme, totale aantal woorde per T-eenheid (TMT: Vorster, 1980), woordherhalings per T-eenheid (TMT: Vorster, 1980), stillees-begrip, en segmentering van 'n sin in afsonderlike woorde.

Bogenoemde resultate is egter teenstrydig met navorsingsresultate en menings van outeurs wat beweer dat taalprobleme 'n sentrale deel van leergestremdheid, en gevolglik ook van taalleergestremdheid uitmaak (ASHA, 1982; Klecan-Aker \& Kelty, 1990).

Hierdie a-tipiese resultate bevestig egter die siening van Nye et al. (1987) wat beweer dat taalleergestremde kinders se taalfunksionering' $n$ merkwaardige verbetering kan toon nadat intensiewe taalintervensieprogramme met hulle gevolg is. Die vraag ontstaan nou egter of die tydstip waarop vroee intervensie toegepas is, moontlik die funksionering van die proefpersone kon beïnvloed.

Die proefpersone in hierdie studie is reeds vanaf driejarige ouderdom in die kleuterafdeling van die betrokke skool ingeskakel. Tydens hierdie pre-geletterdheidsfase het die proefpersone reeds spraakterapie, fisioterapie en/ of arbeidsterapie ontvang. Die proefpersone het intensiewe langtermyn terapie in die kritieke taalaanleerperiode ontvang. Die trans-professionele insette op voorskoolse vlak kon moontlik tot die proefpersone se voordeel gestrek het, aangesien taalopleidingsprogramme soos in hoofstroomonderwys toegepas word, nie noodwendig kompenseer vir die verlies aan stimulasietyd, wat leerlinge met uitvalle wat eers op skoolvlak geïdentifiseer is, ondervind nie (Cole, 1982).

Alhoewel verskeie outeurs die waarde van vroeë intervensie beklemtoon (ASHA, 1988; Louw, 1990), bestaan daar tans verskille tussen outeurs rakende die siening of hoë-risiko-kinders eventueel met spraak- en/of taalprobleme gaan presenteer, al dan nie. Menyuk, Liebergott, Schultz, Chesnick en Ferrier (1991) het bewys dat daar nie 'n verskil bestaan tussen die taalontwikkeling en kognitiewe ontwikkeling van hoë-risiko-kinders (premature babas) en nie-hoë-risiko-kinders (voltermyn-babas) wat as proefpersone in hul studie gedien het nie. Aram, Hack, Hawkins, Weissman en Borawski-Clark (1991) het bewys dat meer nie-hoë-risiko-kinders (voltermyn-babas) met spraak- en taalafwykings presenteer, as kinders in die hoë-risiko-groep.

Aangesien daar tans meningsverskille in die literatuur en navorsing bestaan rakende die invloed van vroeë intervensie op latere ontwikkeling, kan daar nie sonder meer aanvaar word dat die a-tipiese resultate van die proefpersone op van die gesproke taalparameters, geskrewe taalparameters en fonologiese prosesseringsparameters, nie die resultaat is van vroeë intervensie nie. Oosthuizen (1994) is van mening dat vroeë intervensie wel die proefpersoonfunksionering positief beïnloed het, in die opsig dat vroeë inkortings van spraak- en taalontwikkeling, voorlopers vir latere leerprobleme kan wees (Aram \& Nation, 1980). Indien die vroeë ingryping deur die trans-professionele span nie noodwendig as primêre rede vir die proefpersone se funksionering aangevoer kan word nie, moet hul insette noodwendig die uitkoms van die leerprobleme minimaliseer (Nye et al. 1987).

Aard van die horrelasies wat tussen gesproke taal.
parameters, geskrewe taalparameters en fonologie-
se prosesseringsparameters geïdentifiseer is.

Volgens Tabel 6 toon die proefpersone se taalbegrip vir woordklasse en relasies 'n positiewe verband met beide stillees-begrip, asook met die vermoë om sinne in afsonderlike woorde te segmenteer. Die positiewe korrelasie wat statisties by die genoemde parameters geïdentifiseer is, kan moontlik geïnterpreteer word in die lig daarvan dat begrip vir woordklasse en relasies verband hou met die tipe begripsvrae wat aan die proefpersone gestel is, nadat hulle die stillees-leesstuk voltooi het. Indien die proefpersone nie goeie begrip getoon het vir die betekenis van woordklasse en relasies nie, kon hul moontlik 'n inkorting gehad het om sinne in afsonderlike woorde te segmenteer, aangesien die sin eerder as 'n geheelboodskap geinterpreteer is, as bestaande uit 'n aantal individuele woorde. Alhoewel die verband tussen fonologiese prosessering en gesproke taalfunksionering by hierdie groep proefpersone geïdentifiseer is, word verdere navorsing steeds benodig om vas te stel of fonologiese prosessering die oorsaak van gesproke taalfunksionering is, soos deur Stackhouse (1990) beweer word.

Dit blyk dat die proefpersone se vermoë om uitgebreide sinne te begryp 'n positiewe verband met begripsvermoë van 'n prosaleesstuk aangetoon het. Hierdie resultate kan moontlik verklaar word na aanleiding daarvan dat indien die proefpersone nie oor die vermoë beskik om 'n enkele uitgebreide sin soos byvoorbeeld: "Die man praat met die dogtertjie se ma wat in die kar sit" te verstaan nie, hulle nie begrip sal toon vir 'n prosaleesstuk, wat uit 'n hele aantal uitgebreide sinne saamgestel is nie.

Woorddefiniëringsvermoë het 'n negatiewe korrelasie met leesspoed en fonologiese prosessering getoon. Hierdie prestasie kan moontlik verklaar word op grond van die medium (ouditief of visueel) waardeur die proefpersone getoets is, naamlik dat gesproke taal in hierdie geval deur die ouditiewe medium (ouditiewe opdrag), en geskrewe taal deur die visuele medium (geskrewe leesstuk) geëvalueer is. Dit blyk dat die spesifieke meetinstrument wat gebruik word, die resultate kan beïnloed. Die negatiewe korrelasie tussen verbale ekspressie en die vermoë om sinne in individuele woorde te segmenteer kan moontlik verklaar word op grond daarvan dat verbale ekspressie in hierdie geval deur die proefpersone se woorddefiniëringsvermoë bepaal is. Die fonologiese prosesseringsvaardigheid daarenteen, word geëvalueer deur vooraf geformuleerde sinne wat deur die remediërende onderwyseres aan die proefpersoon gestel is, waarvan die fonologiese, morfologiese en sintaktiese sinstrukture nie noodwendig aan die proefpersoon bekend is nie. Hierdie resultate bevestig die standpunt van Stackhouse (1990) en Van Kleeck (1992), naamlik dat taalleergestremde leerlinge met fonologiese prosesseringsprobleme kán presenteer.

Dit blyk dat die proefpersone 'n omgekeerde verband toon tussen die totale aantal woorde wat in ekspressiewe taal gebruik word en stillees-begrip. Taalleergestremde leerlinge toon dikwels ernstige en permanente uitvalle in die begrip en gebruik van meer abstrakte taal (Myers \& 

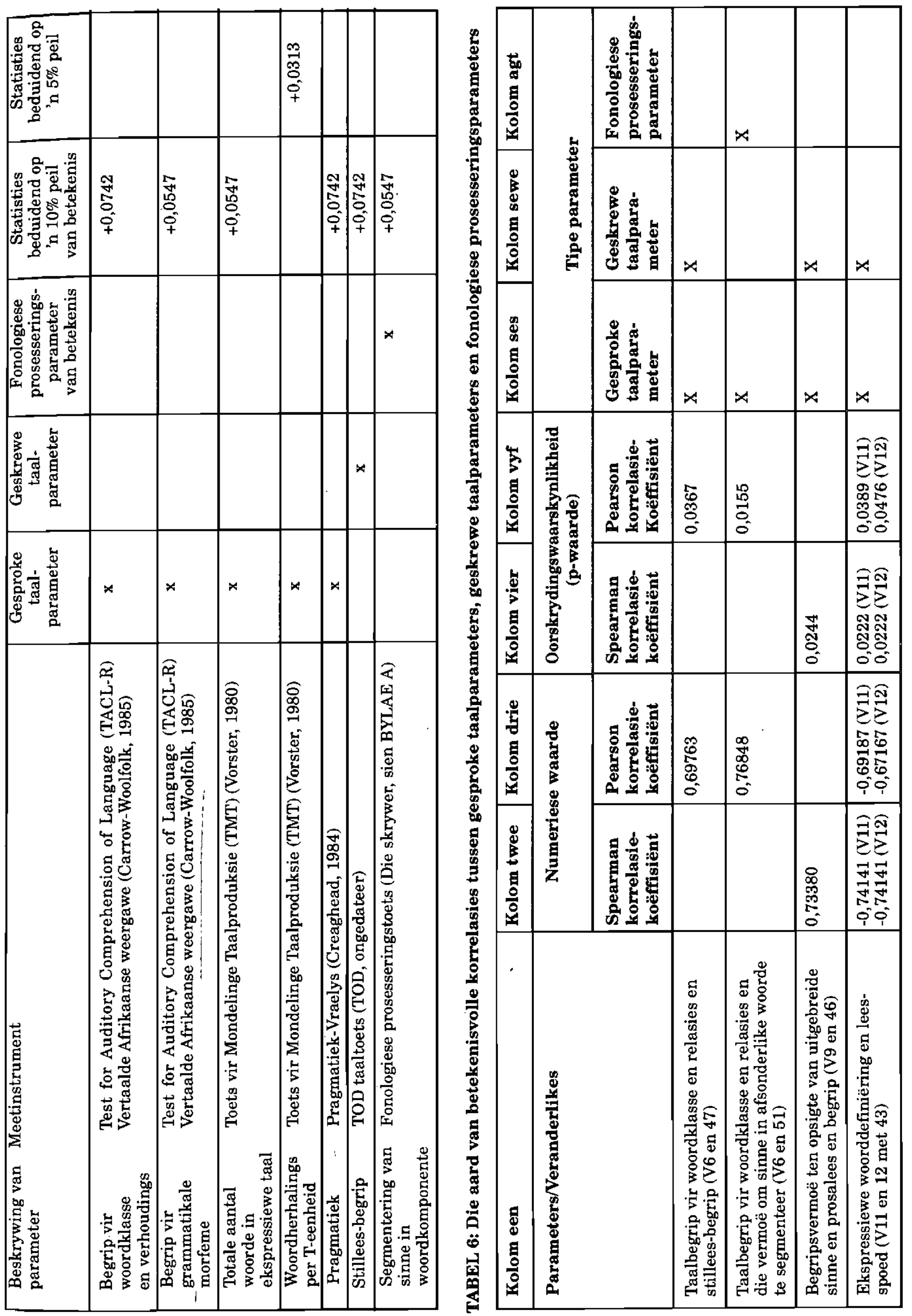

Die Suid-Afrikaanse Tydskrif vir Kommunikasieafwykings, Vol. 42, 1995 


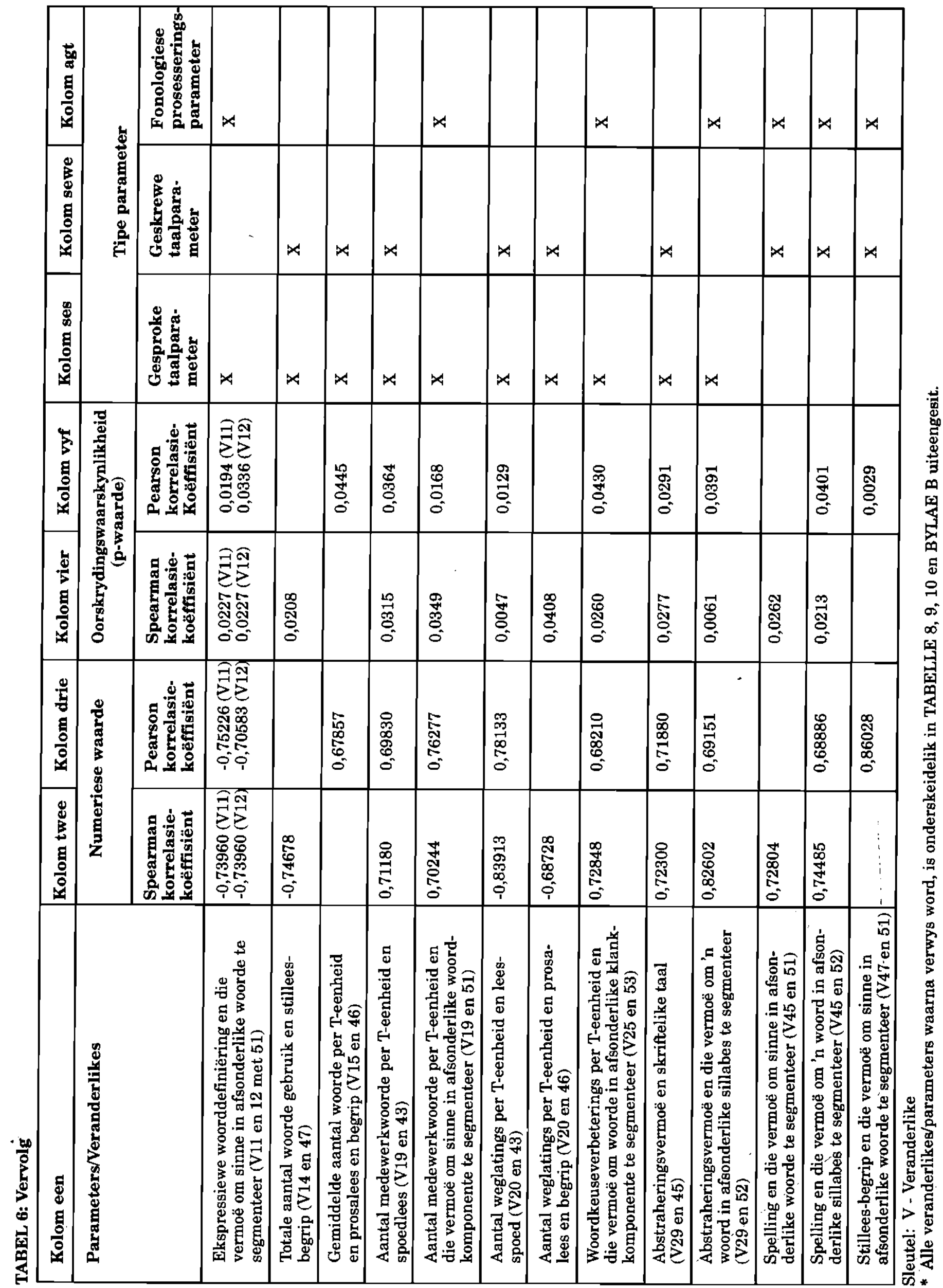


Hammill, 1990). Tydens evaluering van die proefpersone se begrip van 'n stillees-leesstuk word beide konkrete en abstrakte taal as deel van die toetsinhoud voorgelê. Die gevolg is dat'n diskrepansie tussen die toetsprestasies van die proefpersone op hierdie onderskeie twee vaardighede kan bestaan, aangesien spontane gesprekvoering deur middel van konkrete taal kan geskied, terwyl die stilleesbegripstoets uit beide konkrete en abstrakte taalelemente kan bestaan.

Dit blyk dat die proefpersone se funksionering 'n positiewe verband tussen die gemiddelde aantal woorde wat hul gebruik het, en hul begrip vir 'n prosa-leesstuk aangetoon het. Hierdie korrelasie blyk sinvol te wees want hoe groter die woordeskat van die proefpersone is, hoe meer woorde behoort hulle in die prosa-leesstuk te begryp. Vanweë die positiewe aard van die korrelasie, beïnvloed hierdie twee vermoëns mekaar wedersyds. Dit blyk dat die proefpersone se gesproke taalvermoë'n verbetering sal toon indien geskrewe taal 'n verbetering toon en omgekeerd.

Volgens die resultate van die empiriese ondersoek blyk dit dat daar'n positiewe verband bestaan tussen die aantal mede-werkwoorde wat die proefpersone per T-eenheid (TMT: Vorster, 1980) gebruik en spoedleesvermoë, asook tussen die aantal mede-werkwoorde wat die proefpersone per T-eenheid (TMT: Vorster, 1980) gebruik en die proefpersone se vermoë om sinne in onderlinge woorde te segmenteer. 'n Moontlike verklaring vir die positiewe korrelasie tussen die aantal mede-werkwoorde wat die proefpersone per T-eenheid (TMT: Vorster, 1980) gebruik het en hul spoedleesvermoë, kan wees dat werkwoorde dikwels die kernwoord van 'n sin vorm.' 'n Goeie leser lees gevolglik nie noodwendig elke woord in die sin, om die volle boodskap te begryp nie (Leaf, 1994). Aangesien die proefpersone goeie begrip vir mede-werkwoorde toon, en hul spontane spraak as sodanig gekenmerk word deur die gebruik van mede-werkwoorde, kan hul spoedleesvermoë moontlik hierdeur bevoordeel word, deurdat hul in staat is om die mede-werkwoorde en werkwoorde in 'n leesstuk of individueel, te lees en té begryp. 'n Moontlike interpretasie van die geïdentifiseerde positiewe korrelasie wat bepaal is tussen die aantal mede-werkwoorde wat die proefpersone per T-eenheid (TMT: Vorster, 1980) gebruik het en hul vermoë om sinne in onderlinge woorde te segmenteer, kan wees dat die gebruik van werkwoorde en mede-werkwoorde alreeds 'n hoër linguistiese vaardigheid impliseer as met die gebruik van selfstandige naamwoorde (Myers \& Hammill, 1990). Aángesien die proefpersone alreeds hierdie vlak van linguistiese vaardigheid bemeester het, is hul in staat om te begryp dat 'n sin uit afsonderlike woordkomponente bestaan wat eventueel 'n kommunikasieboodskap weergee.

Volgens hierdie ondersoek (Tabel 6) blyk dit dat 'n negatiewe korrelasie geïdentifiseer is tussen die aantal woorde wat die proefpersone per T-eenheid (TMT: Vorster, 1980) weglaat en leesspoed en die aantal woorde wat die proefpersoon per T-eenheid (TMT: Vorster, 1980) weglaat en begrip vir 'n prosa-leesstuk. Dit blyk dat hoe minder woorde die proefpersone per T-eenheid (TMT: Vorster, 1980) weggelaat het, hoe beter hul leesvermoë was. Hoe beter 'n persoon se taalvaardigheid ontwikkel het, hoe minder sal weglatings van woorde in spontane spraak plaasvind. Aangesien 'n persoon met min of geen weglatings van woorde in spontane spraak, alreeds 'n gevorderde vlak van linguistiese ontwikkeling bereik het
(Myers \& Hammill, 1990), blyk dit moontlik te wees dat dié genoemde vaardigheid verband kan hou met leesspoed, aangesien leesspoed ook 'n bepaalde vlak van linguistiese en visueel-perseptuele maturasie vereis. Net so kan die aantal woorde wat ' $n$ proefpersoon in spontane spraak weglaat met begrip vir'n prosa-leesstuk verband hou. Hoe beter 'n persoon se woordeskat ontwikkel is, hoe minder woorde sal hul in spontane spraak weglaat, en hoe beter kan hul begrip moontlik vir 'n prosa-leesstuk wees, aangesien hul bekend is met 'n goed ontwikkelde woordeskatkennis.

Alvorens die proefpersone in staat kan wees om selfkorreksies in spontane spraak te kon toepas, moes hul noodwendig tot' $n$ gevorderde vlak van linguistiese oordeel ontwikkel het, om tussen korrekte en foutiewe uitinge te kon diskrimineer. Net so verg die vermoë om woorde in afsonderlike klankkomponente in te deel'n gesofistikeerde aanvoeling vir die komponente waaruit 'n woord saamgestel is (Van Kleeck, 1992).

Volgens die resultate (Tabel 6) blyk dit dat daar 'n positiewe verband bestaan tussen die proefpersone se abstraheringsvermoë en hul spellingvermoë en die proefpersone se abstraheringsvermoë en hul vermoë om woorde in afsonderlike sillabes te segmenteer. Die rede dat die proefpersone se abstraheringsvermoë met beide hul spellingvermoë en hul vermoë om woorde in afsonderlike sillabes te segmenteer geassosieer word, kan moontlik verklaar word na aanleiding van die verskillende ontwikkelingstadia wat alreeds in 1953 deur Piaget beskryf is (Myers \& Hammill, 1990). Die vermoë om op 'n abstrakte vlak te funksioneer impliseer'n gevorderde vlak van kognitiewe en linguistiese funksionering.

Die resultate van die studie lewer voldoende bewys dat daar 'n verband tussen gesproke taalfunksionering, geskrewe taalfunksionering en fonologiese prosessering by die proefpersone bestaan. Verskeie verklarings kan aangevoer word vir die geidentifiseerde korrelasies, naamlik vlak van linguistiese maturasie, bewussyn van fonologiese struktuur van taal, modaliteitsvoorkeur (visueel of ouditief) en die tipe voorkennis wat benodig word alvorens ' $n$ bepaalde vaardigheid uitgevoer kan word.

Net so impliseer 'n goed ontwikkelde spellingvermoë, asook die vermoë om woorde in afsonderlike sillabes te segmenteer, dat die proefpersoon reeds 'n bewussyn gekweek het van die onderliggende fonologiese strukture waaruit taal bestaan (Van Kleeck, 1992). Die geïdentifiseerde korrelasies hou dus beide verband met hoër taalfunksies, naamlik abstraheringsvermoë en die vermoë om taal in onderlinge eenhede te segmenteer.

Volgens die resultate (Tabel 6) blyk dit dat daar 'n positiewe korrelasie bestaan tussen spellingvermoë en die vermoë om sinne in afsonderlike woorde te segmenteer. Hierdie resultate bevestig die siening van outeurs (Stackhouse, 1990; Kamhi \& Catts, 1991) dat geskrewe taalvermoë en fonologiese prosesseringsvermoë interverwant is. Hierdie korrelasie hou moontlik verband daarmee dat spellingvermoë as sodanig, 'n vermoë impliseer wat die analise en sintese van grafo-foneme behels (Westby \& Costlow, 1991). Hierdie vermoë hou verband met die vermoë van die proefpersone om sinne in afsonderlike woorde te kan segmenteer. Beide hierdie vermoëns hou verband met 'n eksplisiete kennis van taal, naamlik ' $n$ bewussyn van die fonologiese kennis, sowel as 'n aanvoeling vir foneem-grafeem en alfabetiese kennis (Westby \& Costlow, 1991). 
Dit blyk dat daar 'n positiewe verband is tussen begrip vir'n prosa-leesstuk en die vermoë om'n sin in afsonderlike woordkomponente te segmenteer (Tabel 6). Die positiewe korrelasie wat tussen begrip vir 'n prosa-leesstuk en die vermoë om sinne in afsonderlike woordkomponente te segmenteer verkry is, dui eerstens daarop dat, indien die proefpersone 'n voorgeskrewe stuk self gelees het en vrae rakende die leesstuk korrek beantwoord het, hul ook vaardig is om sinne in afsonderlike woordkomponente te segmenteer. Hierdie korrelasie kan moontlik verklaar word deurdat beide hierdie parameters met geheue verband hou (Grové \& Hauptfleisch, 1984; Van Kleeck, 1992). In 'n poging om vrae rakende die prosa-leesstuk te kan beantwoord, moes die proefpersone oor 'n goeie visuele storiegeheue beskik, net so moes die proefpersone oor goeie ouditiewe geheue beskik tydens die fonologiese prosesseringstoets, aangesien 'n gesproke sin op ouditiewe vlak herroep moes word, alvorens die sin in woordkomponente verdeel kon word.

\section{GEVOLGTREKKINGS EN AANBEVELINGS}

Die resultate van hierdie ondersoek lewer voldoende bewys dat daar betekenisvolle korrelasies tussen gesproke taalfunksionering en geskrewe taalfunksionering van die proefpersone bestaan. Hierdie inligting noop die spraak-taalterapeut om die grense van haar dienslewering in heroënskou te neem, in die opsig dat gesproke taalprobleme nie in isolasie aangespreek kan word nie. 'n Moontlike oplossing vir hierdie probleem kan die volgende insluit:

- Die opleiding van die spraak-taalterapeut behoort verbreed te word na ' $n$ in-diepte-opleiding rakende intervensie van alle kommunikasievaardighede wat beide gesproke en geskrewe taalprobleme impliseer.

- 'n Noue trans-professionele benadering behoort gevolg te word, waar die spraak-taalterapeut, remediërende onderwyseres, arbeidsterapeut en opvoedkundige sielkundige as span saam die taalleergestremde kind hanteer.

Die proefpersoonresultate lewer bewys van die verband tussen fonologiese prosessering met beide gesproke en geskrewe taal. Alhoewel die resultate van dié studie 'n korrelasie tussen fonologiese prosessering en gesproke en geskrewe taalfunksionering bewys het, kan daar nie sonder meer aangeneem word dat fonologiese prosessering die onderliggende oorsaak vir gesproke en geskrewe taalfunksionering is, soos deur Stackhouse (1990) beweer word nie.

Die korrelasie wat in die empiriese studie tussen fonologiese prosessering en gesproke en geskrewe taal bepaal is, noodsaak die spraak-taalterapeut om fonologiese prosessering as deel van die toetsbattery van geletterdheidsfunksionering by die taalleergestremde kind te implementeer. Aangesien geen gestandaardiseerde evalueringsmedium tans bestaan om fonologiese prosessering in Afrikaans te evalueer nie, behoort toekomstige navorsing daarop gerig te wees om die ontwikkeling van 'n gestandaardiseerde toetsbattery vir fonologiese prosessering daar te stel.

In die lig van die voorafgaande gevolgtrekkings word die volgende aanbevelings geformuleer, naamlik:
- Alhoewel die resultate die korrelasie tussen fonologiese prosessering en geletterdheidsfunksionering by die proefpersone bevestig, word verdere navorsing steeds benodig om te bepaal of fonologiese prosessering as basiese voorvereiste vir geletterdheidsfunksionering beskou kan word, soos hipoteties deur Stackhouse (1990) beweer word.

- Die ontwerp en ontwikkeling van kultuurvrye gestandaardiseerde evalueringsmedia, waardeur fonologiese prosessering volledig geëvalueer word, behoort daadwerklike aandag in navorsing te geniet. Evalueringsmedia behoort dus voorsiening te maak vir die multikulturele en multilinguistiese opset in die RSA.

- Daar word aanbeveel dat fonologiese prosessering by intervensie van die taalleergestremde kind ingesluit word om as deel van kommunikasievaardighede aangespreek te word (Catts, 1991).

- Aangesien resente publikasies, asook bevindinge van dié empiriese studie, die noue verwantskap tussen gesproke en geskrewe taal erken en bevestig, behoort die kurrikulum waarvolgens spraak-taalterapeute opgelei word in heroënskou geneem te word, om te verseker dat in-diepte kennis rakende intervensie van geskrewe taalprobleme as deel van die opleidingsprogram realiseer.

- Navorsing binne die multikulturele en multilinguistiese domein word aanbeveel, sodat wetenskaplik gefundeerde intervensiebeplanning kan geskied met betrekking tot die hantering van geletterdheidsfunksionering en fonologiese prosessering van die bevolking van die RSA.

- Alhoewel hierdie studie die evaluering van gesproke taal, geskrewe taal en fonologiese prosessering beklemtoon, behoort verdere navorsing daarop gerig te wees om terapeutiese hulpverleningsprogramme daar te stel. Hierdie programme behoort daarop gerig te wees om habilitasie en rehabilitasie van gesproke taalprobleme, geskrewe taalprobleme en fonologiese prosesseringsprobleme van taalleergestremde leerlinge te bewerkstellig.

\section{BIBLIOGRAFIE}

American Speech-Language-Hearing Association :(1988). Prevention of communication disorders: Position statement. American Speech and Hearing Association, 30(3), 90!

American-Speech-Language-Hearing Association (Committee on Language Learning Disabilities) (1982), "Position státement on language-learning disorders." American Speech and Hearing Association, 24(11), 937-944.

Aram, D.M., Hack, M., Hawkins, S., Weissman B.M. \& BorawskiClark, E. (1991). Very-low-birthweight children and speech and language development. Journal of Speech and Hearing Research, 34(5), 1169-1172.

Aram, D. \& Nation, J. (1980). Preschool language disorders and subsequent language and academic difficulties. Journal of Communication Disorders, 13, 159-170.

Carrow-Woolfolk, E. (1985). Test for auditory comprehension of language (TACL-R). Texas: DLM, Teaching Resource.

Catts, H.W. (1991). Facilitating phonological awareness: Role of the speech-language pathologists. Language, Speech and Hearing Services in Schools, 12, 196-203.

Cole, P.R. (1982). Language disorders in preschool children. New Jersey: Prentice-Hall.

Creaghead, N.A. (1984). Strategies for evaluating and targeting pragmatic behaviors in young children. Seminars in Speech and Language 5(9), 241-250.

Fick, M.L. (1939). An individual scale of general intelligence for 
South Africa. Council for Educational and Social Research. Pretoria: Human Sciences Research Council.

Grové, M.C. \& Hauptfleisch, H.M.A.M. (1984). Remediërende onderwys in die primêre skool. Pretoria: HAUM.

Johnson, D.J. \& Myklebust, H.R. (1967). “Learning disabilities. Educational principles and Practices" In: Kamhi, A.G. \& Catts, H.W. (1991). Reading disabilities. A developmental language perspective. United States: Little Brown and Company.

Kamhi, A.G. \& Catts, H.W. (1991). Reading disabilities. A developmental language perspective. United States: Little Brown and Company.

Klecan-Aker, J.S. \& Kelty, K.R. (1990). An investigation of the oral narratives of normal and language-learning disabled children. Journal of Childhood Communication Disorders, 13(2), 207-216.

Leaf, C. (1994). "Mind Mapping Approach." Seminaar: Pretoria. Leedy, P.D. (1989). Practical research. Planning and design. United States of America: Macmillan Publishing Company.

Lloyd, M.D. (1959). Peabody picture vocabulary test. Minnesota: AGS.

Louw, B. (1990). Hoërisiko-kinders. Vroeë programme blyk nodig. Bulletin, 2(1), 4-5.

Madge, E.M. (1981). Junior Suid-Afrikaanse individuele skaal. Pretoria: Raad vir Geesteswetenskaplike Navorsing.

Menyuk, P., Liebergott, J., Schultz, M., Chesnick, M. \& Ferrier, L. (1991). Patterns of early lexical and cognitive development in premature and full-term infants. Journal of Speech and Hearing Research, 34(1), 88-94.

Myers, P.I. \& Hammill, D.D. (1990). Learning disabilities. Austin, Texas: Pro-ed.

Nye, C., Foster, S.H. \& Seaman, D. (1987). Effectiveness of language intervention with the language/learning disabled." Journal of Speech and Hearing Disorders, 52(4), 348-357.

Oosthuizen, J.I. (1994). Die verband tussen gesproke en geskrewe taal van leergestremdes. Ongepubliseerde $\mathrm{M}(\mathrm{L}, \mathrm{g})$ - verhandeling, Universiteit van Pretoria.

Pretorius, A. (1989). Die Afrikaanse semantiese taalevalueringsmedium. Pretoria: A. Pretorius.

Reid, D.K., Hresko, W.P. \& Swanson, H.L. (1991). A Cognitive approach to learning disabilities. Texas: Pro-Ed.

SAVSTG. (1990). "The role of the Speech-Language-Hearing Therapist in the assessment, remediation, planning and management in Language-Learning Individuals." SAVSTG Seminaar: Universiteit van Pretoria.

Stackhouse, J. (1990). Phonological deficits in developmental reading and spelling disorders. In P. Grunwell (Ed.), Developmental Speech Disorders. Singapore: Longman Singapore Publishers.

Struwig, P. (1984). Handleiding van die Pendulum-toets vir ouditiewe persepsie en konseptualisering. Pretoria.

Transvaalse Onderwysdepartement. (Ongedateer). Een-minuutleestoets; K3 Skolastiese Toets; TOD Taaltoets. Transvaalse Onderwysdepartement: Pretoria.

Universiteit van Wes-Kaapland. (Ongedateer). IPV: Spelevalueringstoets. Kaapprovinsie: Universiteit van WesKaapland.

Uys, I.C. (1993). Kommunikasiepatologie: Onderrig vir die toekoms. Die Suid-Afrikaanse Tydskrif vir Kommunikasieafwykings, 40, 3-9.

Van Kleeck, A. (1990). Emergent literacy: Learning about print before learning to read. Topics in Language Disorders, 10(2), $25-45$.

Van Kleeck, A. (1992). "Language assessment and intervention in children: An overview and special focus on preliteracy." SASLHA: Workshop. Department of Speech Pathology and Audiology. University of Pretoria.

Vorster, J. (1980). Toets vir Mondelinge Taalproduksie. Pretoria: Raad vir Geesteswetenskaplike Navorsing.

Westby, C.E. \& Costlow, L. (1991). Implementing a whole language program in a special education class. Topics in Language Disorders, 11(3), 69-84.

\section{BYLAE A Fonologiese Prosesseringstoets}

\section{SUBTOETS 1 SEGMENTERING VAN SINNE IN WOORDKOMPONENTE}

1. Sy sit die brood op die tafel. (Antwoord: 7)

2. Water tap uit 'n kraan. (Antwoord: 5)

3. Die druiwe is op die stoof. (Antwoord: 6)

4. Die olifant, perd en kat word deur die zebra gejaag.

(Antwoord: 10)

5. Sy voer die baba met die lepel. (Antwoord: 7)

6. Die emmer is vol klippe. (Antwoord: 5)

7. Die seuntjie drink. (Antwoord: 3)

8. Hy spring op sy fiets. (Antwoord: 5)

9. Die gogga eet blare. (Antwoord: 4)

10. Die skoene kos baie geld. (Antwoord: 5)

11. Hy speel gholf. (Antwoord: 3)

Punte behaal Maksimum punte

\section{SUBTOETS 2 SEGMENTERING VAN WOORDE IN SILLABES}

1. vurk

2. kwas

3. piesang

4. sjokolade

5. boom

6. knoop

7. vliegtuig

8. seep

9. spons

10. vingers

11. rok

12. stryk

13. masjien

14. neus

15. skryf

16. mielie

17. skrik

18. pleister

19. sleutels

20. wolke

(Antwoord: 1)

(Antwoord: 1)

(Antwoord: 2)

(Antwoord: 4)

(Antwoord: 1)

(Antwoord: 1)

(Antwoord: 2)

(Antwoord: 1)

(Antwoord: 1)

(Antwoord: 2)

(Antwoord: 1)

(Antwoord: 1)

(Antwoord: 2)

(Antwoord: 1)

(Antwoord: 1)

(Antwoord: 2)

(Antwoord: 1)

(Antwoord: 2)

(Antwoord: 2)

(Antwoord: 2)

Punte behaal

Maksimum punte

\section{SUBTOETS 3 SEGMENTERING VAN WOORDE IN KLANKE}
1. jas
2. prop
3. huis
4. glas
5. trein
6. gras
7. swem
8. boks
9. berg

(Antwoord: 3)

(Antwoord: 4)

(Antwoord: 3)

(Antwoord: 4)

(Antwoord: 4)

(Antwoord: 4)

(Antwoord: 4)

(Antwoord: 4)

(Antwoord: 4)

Punte behaal:

Maksimum punte 
BYLAE B: Data-definisie

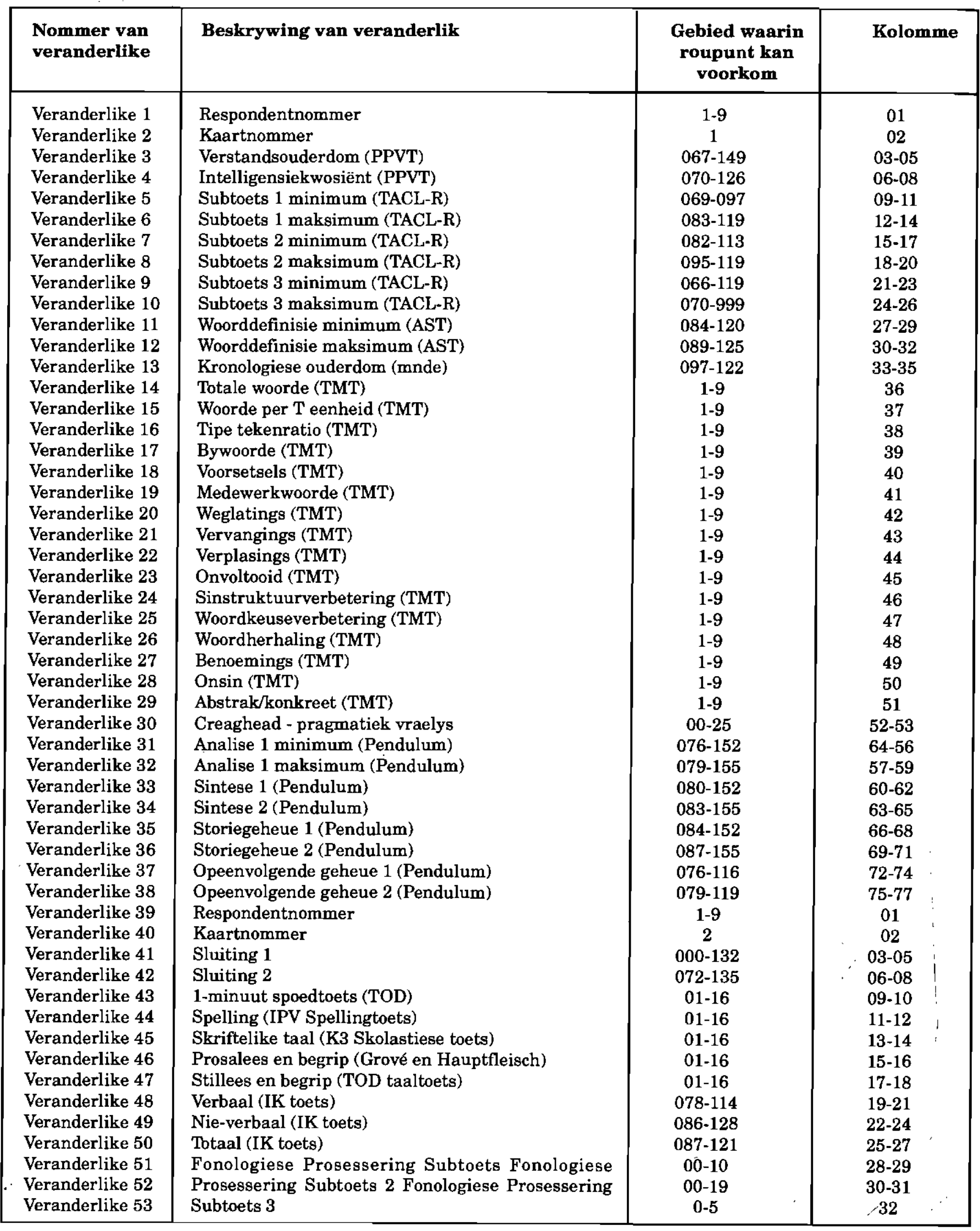

* Alle subtoetse en toetse waarna verwys word, is onderskeidelik in TABELLE 2 en 3 volledig bespreek en uiteengesit. 